\title{
PENGAMBILAN KEPUTUSAN TRANSFER PRICING PADA PERUSAHAAN MULTINASIONAL BERDASARKAN TAX DAN EXCHANGE RATE
}

\author{
Suryani Cahyadi, Budi Kurniawan \\ Universitas Bunda Mulia \\ bkurniawan@bundamulia.ac.id
}

\begin{abstract}
The objective of this research is to prove, analyze the influence of tax and exchange rate on transfer pricing decision in multinational manufacturing companies. Tax is measured using a proxy ETR (Effective Tax Rate), Exchange Rate is measured using a proxy keutungan or loss transactions of companies using foreign currency, and transfer pricing was measured using dummy variables to determine the companies that conduct transactions with related parties. The analysis technique used in this research is regression analysis with the use of categorical variables logit model (Logistic Regression / Binary Choice) or also called logistic regression using EViews 9.5 program for Windows. Based on the results of logistic regression analyzes tested, testing the first hypothesis $\left(H_{1}\right)$ of positive influence Tax on transfer pricing decisions of companies, the result is precisely the opposite direction to that predicted, namely tax significant negative effect on the company transfer pricing decisions. While testing the second hypothesis $\left(\mathrm{H}_{2}\right)$ on the effect of Exchange Rate on transfer pricing decisions the company showed a positive direction but not significant. The results of this study indicate that the tax and exchange rate does not significantly influence transfer pricing indications. The determination coefficient (McFadden R-squared) is 0.023610 . This result show that 2.3\% transfer pricing is affected by tax, and exchange rate. While the rest $97.7 \%$ is explained by other variable that means many other variables in outside of tax, and exchange rate that can explain transfer pricing. Transfer pricing happen on the company with high profit purpose and using tax avoidance become the a to fulfil it, but the higher the tax rate used by the company will lower the company's transfer pricing decisions. The amount of the exchange rate (exchange rate) affects the judgment of the company, whether the company will choose to conduct transfer pricing decisions, or choose not to take a decision of transfer pricing.
\end{abstract}

Keywords: tax, exchange rate, transfer pricing, multinational corporations

\begin{abstract}
ABSTRAK: Tujuan penelitian ini adalah untuk membuktikan, menganalisis dan menguji pengaruh tax dan exchange rate terhadap pengambilan keputusan transfer pricing perusahaan manufaktur multinasional. Tax diukur menggunakan proksi ETR (Effective Tax Rate), Exchange Rate diukur menggunakan proksi keutungan atau kerugian transaksi perusahaan yang menggunakan mata uang asing, dan transfer pricing diukur menggunakan variabel dummy dengan menentukan perusahaan yang melakukan transaksi dengan pihak hubungan istimewa. Teknik analisis yang digunakan pada penelitian ini adalah analisis regresi dengan variabel kategorik penggunaan model logit (Logistic Regression/Binary Choice) atau disebut juga regresi logistik menggunakan program EViews 9.5 for Windows. Berdasarkan hasil analisis regresi logistik yang diuji, pengujian hipotesis pertama $\left(\mathrm{H}_{1}\right)$ tentang pengaruh positif $\boldsymbol{T a x}$ terhadap keputusan transfer pricing perusahaan, hasilnya justru berlawanan arah dengan yang diprediksi, yaitu tax berpengaruh negatif signifikan terhadap keputusan transfer pricing perusahaan. Sementara pengujian hipotesis kedua $\left(\mathrm{H}_{2}\right)$ tentang pengaruh Exchange Rate terhadap keputusan transfer pricing perusahaan menunjukkan arah positif tetapi tidak signifikan. Hasil dari penelitian ini menunjukkan bahwa tax dan exchange rate tidak berpengaruh signifikan terhadap indikasi melakukan transfer pricing. Koefisien Determinasi $\mathrm{R}^{2}$ (McFadden R-squared) sebesar 0.023610. Hasil ini menunjukkan bahwa $2,3 \%$ transfer pricing dipengaruhi oleh variabel tax dan exchange rate. Sedangkan sisanya $97,7 \%$ dipengaruhi oleh variabel lain diluar dari tax dan exchange rate. Transfer pricing muncul pada perusahaan yang ingin laba yang tinggi dan penghindaran pajak sebagai salah satu caranya, tetapi semakin tinggi tarif pajak yang digunakan oleh perusahaan maka akan menurunkan keputusan transfer pricing perusahaan. Besar-kecilnya nilai tukar (exchange rate) mempengaruhi pertimbangan perusahaan, apakah perusahaan akan memilih untuk melakukan keputusan transfer pricing atau memilih untuk tidak melakukan keputusan transfer pricing.
\end{abstract}


Kata Kunci: tax, exchange rate, transfer pricing, perusahaan multinasional

\section{PENDAHULUAN}

Praktik earnings management mulai menjadi perhatian setelah terungkapnya kasus Enron Corporation pada tahun 2001. Perusahaan dinyatakan mendapatkan laba bersih sebesar USD 393 juta, padahal pada periode tersebut perusahaan mengalami kerugian sebesar USD 644 juta yang mendongkrak laba mendekati USD 1 milyar (Purnomo dan Pratiwi, 2009). Kasus praktik earnings management yang menjadi perhatian besar pada saat ini yaitu terungkapnya kasus PT Toshiba Corp pada tahun 2015 yang merupakan perusahaan elektronik besar di Jepang yang memalsukan laporan keuangan dengan meningkatkan pendapatan perusahaan mencapai lebih dari US \$ 1 Milyar. Hal ini didasarkan dari laporan pihak ketiga yang menyatakan bahwa eksekutif perusahaan menetapkan target keuntungan yang tidak realistis yang menyebabkan penundaan pengakuan kerugian hingga enam tahun. Sebagai dampaknya, perusahaan dikenakan denda dan diwajibkan menyajikan kembali laporan laba rugi selama periode akuntansi lebih dari enam tahun (Bloomberg dalam Bisnis.com, 2015).

Metawee (2013) menyatakan praktik earnings management yang menimbulkan kerugian bagi berbagai pihak memunculkan perlunya suatu mekanisme yang dapat diterapkan untuk mengurangi konflik kepentingan yang timbul antara manajer dengan pemegang saham yang dapat meningkatkan kredibilitas dan transparansi informasi keuangan yang dilaporkan. Tekanan globalisasi dan ketatnya persaingan saat ini mengarahkan organisasi untuk menerapkan prinsip corporate governance. Konsep corporate governance mengacu pada pengawasan yang dilakukan manajemen yang terutama oleh dewan komisaris yang berperan dalam proses pengawasan terhadap pembuatan keputusan organisasi yang dilakukan oleh dewan direksi (Nugroho dan Eko, 2011). Corporate Governance menjadi salah satu mekanisme untuk mengurangi biaya agensi yang muncul sebagai dampak dari perbedaan kepentingan antara manajer dan pemegang saham (Hassan dan Ahmad, 2012).

Dalam menjalankan operasi perusahaan diperlukan mekanisme pengawasan internal melalui adanya dewan komisaris, komite audit, dan auditor eksternal. Keberadaan dewan komisaris dapat menjamin pelaksanaan strategi perusahaan, pengawasan pengelolaan perusahaan yang dilakukan dewan direksi, dan menjamin terwujudnya akuntabilitas. Adanya dewan komisaris independen juga dapat meningkatkan proses pembuatan keputusan yang dilakukan dewan direksi menjadi lebih efektif dan akurat karena tidak terpengaruh dengan kondisi internal perusahaan. Komite audit dapat membangun fungsi intermediary dalam mengatasi konflik yang timbul antara manajemen dengan auditor eksternal dan menyesuaikan pandangan mereka untuk menghasilkan laporan keuangan yang akurat. Komite audit independen dapat membantu dewan komisaris dalam melakukan pengawasan kebijakan manajemen secara efektif terhadap perilaku oportunistik manajemen dalam pemilihan metode akuntansi yang berpengaruh terhadap kinerja perusahaan. Keefektifan keberadaan komite audit dapat diketahui dari jumlah rapat yang dilakukan oleh komite audit (Bukit dan Iskandar, 2009).

Permasalahan agensi yang muncul terkait dengan pemisahan kepemilikan dan pengendalian, asimetri informasi yang timbul antara manajer dan pemegang saham, dan kurangnya pengawasan pemegang saham terhadap manajemen menciptakan kebutuhan akan pentingnya audit eksternal. Auditor eksternal berperan dalam memverifikasi laporan keuangan telah disajikan sesuai dengan standar akuntansi yang ada dan menggambarkan kondisi ekonomi dan hasil operasi perusahaan yang sebenarnya. Kualitas auditor eksternal secara langsung dapat meningkatkan kredibilitas laporan keuangan yang dihasilkan dan membatasi perilaku oportunistik yang dilakukan manajer dalam memanipulasi laporan keuangan (Soliman dan Ragab, 2014).

Pengaruh ukuran dewan komisaris terhadap praktik earnings management ditunjukkan pada penelitian Jao dan Pagalung (2012) dan Murtini dan Mansyur (2012) yang membuktikan bahwa ukuran dewan komisaris berpengaruh positif terhadap earnings management serta komposisi dewan komisaris independen berpengaruh negatif terhadap earnings management. Baxter dan Cotter (2009) dalam penelitiannya membukttikan ukuran komite audit 
berpengaruh negatif terhadap praktik earnings management. Soliman dan Ragab (2014) dan Waweru dan Riro (2013) dalam penelitiannya membuktikan ukuran komite audit independen berpengaruh negatif terhadap praktik earnings management. Penelitian yang dilakukan Soliman dan Ragab (2014), Metawee (2013), dan Jao dan Pagulung (2011) membuktikan jumlah rapat komite audit memiliki pengaruh yang negatif dan signifikan terhadap praktik earnings management. Penelitian Soliman dan Ragab (2014) dan Metawee (2013) menunjukkan keahlian keuangan anggota komite audit memiliki pengaruh yang negatif terhadap praktik earnings management. Penelitian yang dilakukan Soliman dan Ragab (2014) dan Swastika (2013) menunjukkan kualitas auditor memiliki pengaruh yang negatif dan signifikan terhadap praktik earnings management. Patrick, et. al (2015), Fanani (2014), dan Rauf, et. al (2012) dalam penelitiannya membuktikan ukuran perusahaan memiliki pengaruh yang positif dan signifikan terhadap praktik earnings management. Soliman dan Ragab (2014), Sukeecheep, et.al (2013), dan Rauf, et al (2012) dalam penelitiannya membuktikan aliran kas dari aktivitas operasi memiliki pengaruh yang negatif dan signifikan terhadap praktik earnings management.

Dengan adanya corporate governance yang dapat menurunkan praktik earnings management, maka peneliti melakukan penelitian untuk menguji seberapa besar pengaruh corporate governance berdasarkan indikator dewan komisaris, komite audit, dan auditor eksternal serta karakteristik perusahaan yang dipengaruhi dari ukuran perusahaan dan aliran kas dari aktivitas operasi. Penelitian ini juga dilakukan karena banyaknya penelitian yang dilakukan pada satu negara tertentu dengan perkembangan kondisi ekonomi dan regulasi yang berbeda dengan negara lainnya, sehingga hasil penelitian yang diperoleh tidak konsisten satu dengan yang lainnya.

Tujuan dari penelitian ini adalah membuktikan secara empiris pengaruh corporate governance dan karakteristik perusahaan terhadap praktik earnings management. Manfaat dari penelitian ini adalah memberikan pengetahuan mengenai hal-hal yang berhubungan dengan praktik earnings management yang terjadi pada perusahaan publik sektor manufaktur dan memberikan referensi bagi peneliti selanjutnya yang ingin melakukan penelitian dengan topik sejenis dengan pengembangan yang lebih luas, memberikan pertimbangan pada investor dalam membuat keputusan investasi, dan memberikan informasi bagi manajemen perusahaan untuk menentukan seberapa besar dampak yang timbul dari adanya praktik earnings management terhadap stakeholder.

\section{TINJAUAN PUSTAKA}

\section{Kerangka Teoritis Teori Agensi}

Menurut Godfrey, et. al (2013), teori agensi menyiratkan adanya hubungan keagenan di mana satu atau lebih orang (principal) memerintahkan orang lain (agent) untuk melakukan jasa atas nama principal serta memberi wewenang kepada agent untuk membuat keputusan bagi principal. Berdasarkan teori agensi, yang dimaksud dengan principal adalah pemilik perusahaan yang dalam hal ini merupakan pemegang saham dan yang dimaksud dengan agent adalah manajer yang merupakan pengelola perusahaan. Dalam hubungan keagenan terjadi pemisahan kepentingan antara pemilik perusahaan (principal) dan pengelola perusahaan (agent).

Jensen dan Meckling (1976) menyatakan pemegang saham (principal) dan manajer (agent) memiliki kepentingan yang berbeda yang mana pemegang saham berharap manajer dapat bertindak sesuai dengan kepentingan pemegang saham. Manajer memiliki delegasi dan otoritas penuh untuk membuat keputusan yang dapat memberikan keuntungan bagi dirinya sendiri. Pemegang saham dalam hal ini berupaya untuk membatasi agar keputusan yang dibuat manajer sesuai dengan kepentingan pemegang saham dengan mengeluarkan biaya agensi melalui insentif yang diberikan kepada manajer.

\section{Teori Akuntansi Positif}

Teori akuntansi positif yaitu teori yang menjelaskan praktik akuntansi yang ada saat ini dan alasan praktik tersebut dapat terjadi (Godfrey, 2013). Watts dan 
Zimmerman (1990) dalam Purwanti dan Kurniawan (2013) menyatakan terdapat tiga hipotesis yang dijadikan basis untuk pemahaman earnings management berdasarkan teori akuntansi positif yaitu bonus plan hypothesis, debt covenant hypothesis, dan political cost hypothesis.

1. Bonus Plan Hypothesis. Manajer perusahaan yang mempunyai perencanaan bonus akan memilih metode akuntansi yang dapat menggeser laba bersih dari periode masa depan ke periode saat ini untuk meningkatkan laba bersih yang diperoleh perusahaan saat ini.

2. Debt covenant hypothesis (debt to equity hypothesis). Pada perusahaan yang memiliki rasio debt to equity yang tinggi, manajer perusahaan akan berupaya menggunakan metode akuntansi yang dapat meningkatkan laba bersih perusahaan.

3. Political Cost Hypothesis (Hypothesis Size). Pada perusahaan besar yang memiliki biaya politis yang tinggi, manajer akan memilih untuk menangguhkan laba bersih yang dilaporkan pada periode saat ini ke periode di masa depan untuk meminimalkan laba bersih yang dilaporkan perusahaan.

\section{Praktik Earnings Management}

Schipper (1989) dalam Wahyono, et. al (2013) menyatakan earnings management merupakan intervensi yang dilakukan perusahaan dalam menyusun laporan keuangan untuk memaksimalkan keuntungan pribadi. Healy dan Wahlen (1999) menyatakan bahwa perusahaan melakukan praktik earnings management ketika manajer memiliki beragam cara untuk menerapkan pertimbangan dari sisi biaya dan keuntungan yang diperoleh dalam membuat laporan keuangan dan praktik tersebut pada akhirnya menyesatkan stakeholder mengenai kinerja perusahaan sesungguhnya.

Scott (2013) menyatakan praktik earnings management dari sisi perspektif kontrak bisa digunakan sebagai mekanisme perlindungan perusahaan yang berbiaya rendah dari konsekuensi atas realisasi keadaan yang tidak terduga dari kontrak yang belum selesai, sedangkan dari sisi perspektif pelaporan keuangan, manajer dapat meningkatkan nilai pasar saham perusahaan melalui praktik earnings management. Beberapa motivasi perusahaan dalam melakukan praktik earnings management yaitu kontrak bonus, stock price effect, faktor politik, faktor pajak, dan penawaran saham perdana.

1. Kontrak bonus. Manajer yang memiliki informasi laba bersih perusahaan akan bertindak secara oportunistik untuk memaksimalkan laba saat ini dengan tujuan untuk memperoleh bonus yang besar.

2. Stock price effect. Manajer dapat meningkatkan laba untuk mempengaruhi persepsi investor. Informasi laba yang tinggi yang disampaikan perusahaan ke pasar memegang peran penting dalam meningkatkan harga saham perusahaan.

3. Faktor politik. Manajer dapat mengurangi laba yang dilaporkan kepada publik karena adanya tekanan dari publik yang mengakibatkan pemerintah menetapkan peraturan yang lebih ketat.

4. Faktor pajak. Manajer dapat melaporkan laba yang lebih kecil untuk penghematan pajak pendapatan perusahaan.

5. Penawaran saham perdana. Bagi perusahaan yang akan go public dan belum memiliki nilai pasar, manajer perusahaan dapat meningkatkan laba perusahaan yang meningkatkan nilai jual prospektus yang berpengaruh terhadap peningkatan nilai saham perusahaan.

Scott (2013) menyatakan terdapat beberapa pola yang diterapkan perusahaan dalam melakukan praktik earnings management yaitu taking a bath, income minimization, income maximization, income smoothing, offsetting extraordinary gain, aggressive accounting applications, serta timing revenue and expense recognition. 
1. Taking a bath terjadi saat pengangkatan $\mathrm{CEO}$ baru dengan melaporkan kerugian dalam jumlah besar yang diharapkan dapat meningkatkan laba di masa mendatang.

2. Income minimization dilakukan saat perusahaan memiliki tingkat profitabilitas yang tinggi, sehingga jika laba mendatang turun drastis dapat mengambil laba periode sebelumnya.

3. Income maximization dilakukan saat laba menurun yang bertujuan untuk melaporkan tingkat profitabilitas yang lebih tinggi untuk tujuan memperoleh bonus yang lebih besar.

4. Income smoothing dilakukan perusahaan dengan cara meratakan laba yang dilaporkan, sehingga dapat mengurangi fluktuasi laba yang terlalu besar karena investor lebih menyukai laba perusahaan yang relatif stabil.

5. Offsetting extraordinary gain dilakukan dengan memindahkan pengaruh laba yang tidak biasa atau berlawanan dengan tren laba saat ini.

6. Aggressive accounting applications dilakukan dengan kebijakan salah saji dalam membagi laba antar periode.

7. Timing revenue and expense recognition dilakukan dengan kebijakan yang menyesuaikan jenis transaksi.

\section{Corporate Governance}

Cadbury Commitee of United Kingdom (IICG) mendefinisikan corporate governance sebagai struktur, sistem, dan proses yang digunakan untuk memberikan nilai tambah bagi perusahaan secara berkesinambungan dalam jangka panjang (Wardhani dan Joseph, 2010). Forum for Good Corporate Governance in Indonesia (2001) menyatakan corporate governance memberikan manfaat bagi perusahaan sebagai berikut.

1. Meningkatkan kinerja perusahaan melalui terciptanya proses pengambilan keputusan yang lebih baik, meningkatkan efisiensi operasional, dan meningkatkan pelayanan kepada stakeholders.

2. Meningkatkan nilai perusahaan melalui perolehan dana pembiayaan yang lebih murah.

3. Meningkatkan kepercayaan investor untuk menanamkan modalnya di Indonesia.

4. Meningkatkan kepuasan pemegang saham terhadap kinerja perusahaan yang meningkatkan nilai pemegang saham dan perolehan dividen.

\section{Pengembangan Hipotesis}

Gambar 1 menunjukkan skema kerangka pemikiran yang menjadi dasar perumusan hipotesis pada penelitian ini yaitu untuk membuktikan pengaruh corporate governance, ukuran perusahaan, dan aliran kas dari aktivitas operasi terhadap praktik earnings management.

\section{Ukuran Dewan Komisaris dan Praktik Earnings Management}

Ukuran dewan komisaris merupakan jumlah keseluruhan anggota dewan komisaris, baik yang berasal dari internal dan eksternal perusahaan (Murtini dan Mansyur, 2012). Menurut Komite Nasional Kebijakan Governance (2006), dewan komisaris merupakan organ perusahaan yang bertugas dan bertanggung jawab untuk melakukan pengawasan dan memberikan nasihat kepada direksi. Ukuran dewan komisaris yang besar dapat menurunkan kinerja perusahaan karena dapat memunculkan konflik keagenan yang terjadi antara dewan komisaris dengan manajemen yang meningkatkan terjadinya praktik earnings management yang dilakukan manajemen (Wahyono, et.al, 2013).

$\mathrm{Ha}_{1}$ : Ukuran dewan komisaris berpengaruh positif terhadap praktik earnings management.

\section{Komposisi Dewan Komisaris Independen dan Praktik Earnings Management}

Dewan komisaris independen adalah anggota dewan komisaris yang tidak terafiliasi dengan manajemen di luar perusahaan dan pemegang saham pengendali yang terbebas dari hubungan bisnis dan hubungan lainnya yang dapat mempengaruhi kemampuannya untuk bertindak independen 
atau bertindak untuk kepentingan perusahaan (Ratnaningsih dan Hidayati, 2012). Komposisi dewan komisaris independen yang tinggi dapat meningkatkan independensi pada pengawasan yang dilakukan terhadap manajemen dan anggota dewan komisaris yang lain (Waweru dan Riro, 2013).

$\mathrm{Ha}_{2}$ : Komposisi dewan komisaris independen berpengaruh negatif terhadap praktik earnings management.

\section{Ukuran Komite Audit dan Praktik Earnings Management}

Komite audit merupakan komite yang dibentuk oleh dewan komisaris dalam melakukan pengawasan terhadap pengelolaan perusahaan. BEI (2011) menyatakan komite audit membantu dewan komisaris memastikan bahwa perseroan telah menyajikan laporan keuangan secara wajar sesuai dengan prinsip akuntansi yang berlaku umum, menerapkan pengendalian internal dan manajemen resiko, dan mengawasi fungsi audit eksternal dan internal berjalan dengan baik. Keberadaan komite audit diharapkan dapat menemukan sejak dini praktik yang bertentangan dengan asas keterbukaan informasi pada laporan keuangan, sehingga diharapkan dapat mengurangi praktik earnings management yang dilakukan manajemen (Soliman dan Ragab, 2014).

$\mathrm{Ha}_{3}$ : Ukuran komite audit berpengaruh negatif terhadap praktik earnings management.

\section{Komposisi Komite Audit Independen dan Praktik Earnings Management}

Komite audit independen merupakan anggota komite audit yang berasal dari luar perusahaan yang bertujuan sebagai penghubung antara perusahaan dan pemegang saham untuk melindungi kepentingan pemegang saham dalam hal kualitas laporan keuangan perusahaan (Wahyono, et.al, 2013). Komite audit independen sulit dipengaruhi oleh manajemen sehingga dapat melindungi kepentingan pemegang saham dari tindakan earnings management yang dilakukan manajemen (Sriwedari, 2012).

\section{$\mathrm{Ha}_{4}$ : Komposisi komite audit independen berpengaruh negatif terhadap praktik earnings management.}

\section{Jumlah Rapat Komite Audit dan Praktik Earnings Management}

Rapat komite audit menjadi salah satu indikator adanya interaksi dan aktivitas komite audit dalam menjalankan fungsinya untuk melakukan pengawasan terhadap dewan komisaris (Lipton dan Lorsch, 1992 dalam Siam, et. al, 2014). Komite audit dalam menjalankan tugasnya secara efektif dituntut melakukan rapat secara periodik dengan pihak manajemen, auditor internal, dan auditor eksternal untuk meyakinkan bahwa proses pelaporan keuangan berjalan secara efektif (Fanani, 2014). Semakin tinggi frekuensi jumlah rapat komite audit, maka fungsi pengawasan pengelolaan perusahaan dapat meningkat yang dapat menurunkan praktik earnings management yang dilakukan perusahaan (Siam, et.al, 2014).

$\mathrm{Ha}_{5}$ : Jumlah rapat komite audit berpengaruh negatif terhadap praktik earnings management.

\section{Keahlian Keuangan Anggota Komite Audit dan Praktik Earnings Management}

Anggota komite audit dalam memonitor proses pelaporan keuangan harus memiliki latar belakang pendidikan dan pengalaman akuntansi atau keuangan serta pengetahuan yang memadai mengenai peraturan perundang-undangan di bidang pasar modal dalam rangka mengendalikan manipulasi dan membuat informasi pada laporan keuangan menjadi lebih transparan. Anggota komite audit yang menemukan salah saji yang lebih dini pada laporan keuangan dapat membuat laporan keuangan menjadi lebih credible karena sudah dikoreksi sesuai dengan standar akuntansi yang dijalankan oleh perusahaan (Soliman dan Ragab, 2014).

$\mathrm{Ha}_{6}$ : Keahlian keuangan anggota komite audit berpengaruh negatif terhadap praktik earnings management.

\section{Kualitas Auditor dan Praktik Earnings Management}

Menurut Soliman dan Ragab (2014), auditor bertindak sebagai pihak ketiga yang membantu memitigasi informasi asimetri dan 
konflik kepentingan yang terjadi antara manajer dan pemegang saham. Terdapat dua peran auditor yaitu peran informatif dalam memverifikasi laporan keuangan sebelum diterbitkan dan peran penjamin yang bertanggung jawab terhadap kerugian yang dialami pengguna laporan keuangan. Reputasi auditor yang tinggi dapat meningkatkan mekanisme kontrol dalam mengendalikan kebijakan manajemen, sehingga dapat mengurangi tindakan manajer dalam melakukan praktik earnings management.

$\mathrm{Ha}_{7}$ : Kualitas auditor berpengaruh negatif terhadap praktik earnings management.

\section{Ukuran Perusahaan dan Praktik Earnings Management}

Ukuran perusahaan menggambarkan besar kecilnya suatu perusahaan. Perusahaan berukuran besar memiliki sistem kontrol internal yang lebih rumit dan internal auditor yang lebih kompeten dibandingkan perusahaan berukuran kecil. Perusahaan berukuran besar memiliki aprepriasi yang lebih baik pada lingkungan pasar, kontrol yang lebih baik terhadap operasi, dan pemahaman yang lebih baik terhadap kolega bisnis dibandingkan perusahaan kecil (Rahmani dan Akbari, 2013). Perusahaan berukuran besar cenderung memerlukan dana yang lebih besar dibandingkan perusahaan berukuran kecil yang mendorong pihak manajemen untuk melakukan praktik earnings management, sehingga dengan pelaporan laba yang lebih tinggi maka calon investor maupun kreditur akan tertarik untuk menanamkan dananya kepada perusahaan tersebut (Agustia, 2013).

$\mathrm{Ha}_{8}$ : Ukuran perusahaan berpengaruh positif terhadap praktik earnings management.

\section{Aliran Kas dari Aktivitas Operasi dan Praktik Earnings Management}

Menurut Kieso, et. al (2012), aliran kas dari aktivitas operasi berasal dari transaksi dan peristiwa lain yang mempengaruhi kas yang menjadi penentu laba atau rugi bersih meliputi penerimaan kas dari penjualan barang dan jasa, pengeluaran kas kepada pemasok barang dan jasa, dan pengeluaran kas untuk kepentingan karyawan. Perusahaan dengan aliran kas dari aktivitas operasi yang tinggi cenderung tidak akan melakukan pengaturan laba dikarenakan perusahaan sudah memiliki kinerja keuangan yang baik. Perusahaan dengan aliran kas dari aktivitas operasi yang rendah cenderung akan melakukan pengaturan dengan meningkatkan laba untuk mengirimkan sinyal positif ke investor bahwa perusahaan memiliki kinerja keuangan yang baik (Rauf, et.al, 2012).

$\mathrm{Ha}_{9}$ : Aliran kas dari aktivitas operasi berpengaruh negatif terhadap praktik earnings management.

\section{METODE PENELITIAN}

\section{Rancangan Penelitian}

Penelitian ini menggunakan metode pengumpulan data sekunder melalui pooling data time series yang dilakukan dalam waktu yang berurutan dari tahun 2011-2014 dengan data sekunder yang bersumber dari laporan tahunan perusahaan. Lingkungan setting yang digunakan dalam penelitian ini adalah lingkungan riil. Unit analisis yang digunakan dalam penelitian ini adalah perusahaan.

Data dikumpulkan dengan menggunakan metode dokumentasi melalui pengumpulan sumber data sekunder. Populasi dari penelitian ini yaitu seluruh perusahaan yang terdaftar di Bursa Efek Indonesia. Sampel yang digunakan dalam penelitian ini yaitu seluruh perusahaan manufaktur yang terdaftar di Bursa Efek Indonesia dari tahun 2011-2014. Metode pengambilan sampel pada penelitian ini menggunakan purposive sampling method dengan kriteria pemilihan sampel adalah sebagai berikut.

1. Perusahaan manufaktur yang terdaftar di Bursa Efek Indonesia secara konsisten dari tahun $2011-2014$.

2. Perusahaan manufaktur yang menerbitkan laporan keuangan pada akhir tahun fiskal 31 Desember secara konsisten dari tahun $2011-2014$.

3. Perusahaan manufaktur yang menerbitkan laporan keuangan dalam mata uang rupiah secara konsisten dari tahun $2011-2014$.

4. Perusahaan manufaktur yang memiliki aliran kas dari aktivitas operasi yang 
positif secara konsisten dari tahun 2011 2014.

5. Perusahaan manufaktur yang memiliki laba bersih yang positif secara konsisten dari tahun 2011 - 2014.

6. Perusahaan manufaktur yang mengungkapkan informasi corporate governance secara lengkap dalam laporan tahunan perusahaan dari tahun $2011-2014$.

\section{Definisi Operasional Variabel dan Pengukuran}

Variabel yang digunakan dalam penelitian ini terdiri dari variabel dependen (praktik earnings management) dan variabel independen (ukuran dewan komisaris, komposisi dewan komisaris independen, ukuran komite audit, komposisi komite audit independen, jumlah rapat komite audit, keahlian keuangan anggota komite audit, kualitas auditor, ukuran perusahaan, dan aliran kas dari aktivitas operasi).

\section{Praktik Earnings Management}

Scott (2013) mendefinisikan earnings management sebagai tindakan yang dilakukan manajemen perusahaan untuk memperoleh tujuan tertentu yaitu memenuhi kepentingannya sendiri atau meningkatkan nilai perusahaan melalui pilihan alternatif kebijakan akuntansi yang ada. Praktik earnings management untuk penelitian ini dalam pengukurannya direplikasi dari Soliman dan Ragab (2014) menggunakan Modified Jones Model. Modified Jones Model merupakan modifikasi dari model Jones (1991) oleh Dechow, et.al (1995) dengan dimensi discretionary accruals (Sukeecheep, et.al, 2013). Dalam menentukan nilai discretionary accruals, nilai Total Current Accruals (TCA) dihitung terlebih dahulu dengan persamaan berikut.

$\mathbf{T C A}_{\text {it }}=\mathbf{N I}_{\text {it }}-\mathbf{C F O}_{\text {it }}$

$\mathrm{TCA}_{\mathrm{it}}=$ Total Current Accruals untuk perusahaan i pada periode $\mathrm{t}$

$\mathrm{NI}_{\text {it }}=$ Laba bersih untuk perusahaan $\mathrm{i}$ pada periode $\mathrm{t}$

$\mathrm{CFO}_{\text {it }}=$ Aliran kas dari aktivitas operasi untuk perusahaan i pada periode $\mathrm{t}$

Selanjutnya, dilakukan regresi Ordinary Least Square (OLS) untuk memperoleh nilai koefisien regresi $\beta_{1}, \quad \beta_{2}, \quad \beta_{3}$ dengan menggunakan model persamaan regresi sebagai berikut.

$\mathbf{T C A} \mathbf{A}_{i t} / \mathbf{A}_{\text {it-1 }}=\boldsymbol{\beta}_{1}\left(1 / \mathbf{A}_{\text {it-1 }}\right)+\boldsymbol{\beta}_{\mathbf{2}}$

$\left(\Delta \operatorname{Rev}_{i t} / A_{i t-1}-\Delta \operatorname{Rec}_{i t} / A_{i t-1}\right)+\beta_{3}$

$\left(\mathbf{P P E}_{i t} / \mathbf{A}_{i t-1}\right)+\mathbf{e}_{i t}$
$\mathrm{TCA}_{\mathrm{it}} / \mathrm{A}_{\mathrm{it}-1}=$ Total Current Accruals / Total aset perusahaan i pada periode $\mathrm{t}$

$\mathrm{A}_{\mathrm{it}-1}=$ Total aktiva pada periode $\mathrm{t}-1$

$\Delta \mathrm{REV}_{\mathrm{it}}=$ Perubahan pendapatan perusahaan $\mathrm{i}$ pada periode $t$ dan $t-1$

$\triangle \mathrm{REC}_{\mathrm{it}}=$ Perubahan piutang bersih perusahaan i pada periode $t$ dan $t-1$

$\mathrm{PPE}_{\mathrm{it}}=$ Aktiva tetap perusahaan $\mathrm{i}$ pada periode $\mathrm{t}$

$\mathrm{e}_{\mathrm{it}}=$ Error

Setelah memperoleh nilai koefisien regresi $\beta_{1}, \beta_{2}, \beta_{3}$, maka data tersebut digunakan untuk menentukan nilai non discretionary accruals (NDA) yang dapat dihitung dengan persamaan berikut.

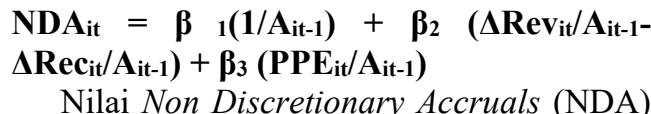

Nilai Non Discretionary Accruals (NDA)
ang diperoleh dimasukkan ke persamaan berikut untuk menentukan nilai Discretionary Accruals (DA).

\section{$\mathbf{D A} A_{i t}=\mathbf{T C A}_{i t} / \mathbf{A}_{\mathbf{i t}-1}-\mathbf{N D A} A_{i t}$}

Apabila nilai discretionary accruals sama dengan 0, maka dapat diindikasikan perusahaan tidak melakukan praktik earnings management. Apabila discretionary accruals bernilai positif, maka diindikasikan perusahaan melakukan praktik earnings management dengan pola meningkatkan laba. Apabila discretionary accruals bernilai negatif, maka diindikasikan perusahaan melakukan praktik earnings management dengan pola menurunkan laba.

\section{Ukuran Dewan Komisaris}

Ukuran dewan komisaris merupakan jumlah anggota dewan komisaris perusahaan, baik yang berasal dari internal maupun eksternal perusahaan (Murtini dan Mansyur, 2012). Pengukuran variabel ukuran dewan komisaris direplikasi dari Natalia dan Eko (2013) yang mengukur ukuran dewan komisaris berdasarkan jumlah seluruh anggota dewan komisaris.

\section{Komposisi Dewan Komisaris Independen}

Dewan komisaris independen adalah anggota dewan komisaris yang tidak terafiliasi dengan manajemen di luar perusahaan dan pemegang saham pengendali yang terbebas dari hubungan bisnis dan hubungan lainnya yang dapat mempengaruhi kemampuannya untuk bertindak independen atau bertindak untuk kepentingan perusahaan 
(Ratnaningsih dan Hidayati, 2012). Pengukuran komposisi dewan komisaris independen konsisten dengan Murtini dan Mansyur (2012) yang mengukur komposisi dewan komisaris independen berdasarkan proporsi jumlah anggota dewan komisaris yang berasal dari luar perusahaan dari seluruh anggota dewan komisaris perusahaan.

\section{Ukuran Komite Audit}

Ukuran komite audit adalah banyaknya jumlah anggota komite audit yang diperlukan untuk menjalankan fungsi pengawasan secara efektif dalam suatu perusahaan (Sukeecheep, et.al, 2013). Pengukuran ukuran komite audit konsisten dengan Soliman dan Ragab (2014) yang mengukur ukuran komite audit berdasarkan jumlah seluruh anggota komite audit baik berasal dari internal maupun eksternal perusahaan.

\section{Komposisi Komite Audit Independen}

Komite audit independen merupakan anggota di luar eksekutif perusahaan yang dapat menghasilkan pengawasan yang lebih efektif dan pelaporan keuangan yang lebih baik (Soliman dan Ragab, 2014). Pengukuran komposisi komite audit independen direplikasi dari Guna dan Herawaty (2010) berdasarkan proporsi anggota komite audit independen terhadap seluruh anggota komite audit.

\section{Jumlah Rapat Komite Audit}

Jumlah rapat komite audit adalah banyaknya jumlah pertemuan yang diselenggarakan komite audit untuk membantu dewan komisaris dalam memenuhi tanggung jawabnya memberikan pengawasan secara menyeluruh terhadap dewan direksi (Jao dan Pagulung, 2011). Jumlah rapat komite audit dalam pengukurannya konsisten dengan Soliman dan Ragab (2014) yang mengukur jumlah rapat komite audit berdasarkan jumlah rapat yang dilakukan komite audit setiap tahun.

\section{Keahlian Keuangan Anggota Komite Audit}

Keahlian keuangan anggota komite audit merupakan pengalaman keuangan yang relevan yang dimiliki anggota komite audit yang tidak terbatas hanya pada seseorang yang memiliki kualifikasi pendidikan profesional akuntan (Soliman dan Ragab, 2014). Pengukuran keahlian keuangan anggota komite audit konsisten dengan Soliman dan Ragab (2014) yang menggunakan variable dummy yaitu 1 jika paling sedikit salah satu dari anggota komite audit memiliki keahlian keuangan dan 0 jika tidak terdapat anggota komite audit yang memiliki keahlian keuangan.

\section{Kualitas Auditor}

Kualitas auditor menurut Soliman dan Ragab (2014) yaitu auditor yang memiliki independensi dalam membatasi kemampuan klien untuk mengatur pendapatan perusahaan. Pengukuran kualitas auditor konsisten dengan Murtini dan Mansyur (2012) yang menggunakan variable dummy yaitu 1 jika perusahaan menggunakan KAP Big Four dan 0 jika perusahaan menggunakan KAP Non Big Four dalam proses pengauditan laporan keuangan.

\section{Ukuran Perusahaan}

Utami dan Prastiti (2011) menyatakan ukuran perusahaan menggambarkan besar kecilnya perusahaan dan strukur kepemilikan perusahaan yang lebih luas. Ukuran perusahaan dapat menggunakan proksi jumlah karyawan, total aset, volume penjualan, dan kapitalisasi pasar. Pengukuran ukuran perusahaan konsisten dengan Soliman dan Ragab (2014) yang mengukur ukuran perusahaan berdasarkan logaritma natural dari total aset.

\section{Aliran Kas dari Aktivitas Operasi}

Menurut Kieso, et. al (2012), aliran kas dari aktivitas operasi merupakan transaksi yang mempengaruhi kas yang menjadi penentu laba bersih meliputi penerimaan kas dari penjualan barang dan jasa, pengeluaran kas ke pemasok dan karyawan. Pengukuran aliran kas dari aktivitas operasi konsisten dengan Soliman dan Ragab (2014) yang mengukur aliran kas dari aktivitas operasi berdasarkan perbandingan aliran kas dari aktivitas operasi terhadap total aset pada awal periode.

\section{Metode Pengumpulan Data}

Data dikumpulkan dengan menggunakan metode dokumentasi melalui pengumpulan sumber data sekunder. Populasi dari penelitian ini yaitu seluruh perusahaan yang terdaftar di Bursa Efek Indonesia. Sampel yang digunakan dalam penelitian ini yaitu seluruh perusahaan manufaktur yang terdaftar di Bursa Efek Indonesia dari tahun 2011-2014. Pengambilan sampel pada penelitian ini menggunakan metode time series. Metode pemilihan sampel yang 
digunakan adalah purposive sampling method. Kriteria pemilihan sampel sebagai berikut.

1. Perusahaan manufaktur yang terdaftar di Bursa Efek Indonesia secara konsisten dari tahun 2011 - 2014.

2. Perusahaan manufaktur yang menerbitkan laporan keuangan pada akhir tahun fiskal 31 Desember secara konsisten dari tahun $2011-2014$.

3. Perusahaan manufaktur yang menerbitkan laporan keuangan dalam mata uang rupiah secara konsisten dari tahun 2011 - 2014.

4. Perusahaan manufaktur yang memiliki aliran kas dari aktivitas operasi yang positif secara konsisten dari tahun 2011 2014.

5. Perusahaan manufaktur yang mengungkapkan informasi good corporate governance secara lengkap dari tahun $2011-2014$.

\section{Metode Analisis Data}

\section{Statistik deskriptif}

Statistik deskriptif yang digunakan dalam penelitian ini meliputi rata-rata, minimum, maksimum, dan standar deviasi. Pengujian ini dilakukan dengan menggunakan SPSS versi 19.0.

\section{Uji Asumsi Klasik}

Uji asumsi klasik yang digunakan dalam penelitian ini adalah uji normalitas, multikolinearitas, heteroskedastisitas, dan autokorelasi.

\section{Uji Normalitas}

Uji normalitas bertujuan menentukan model regresi memiliki data variabel dependen dan variabel independen yang berdistribusi normal atau tidak berdistribusi normal. Jika nilai asymp.sig. (2-tailed) di atas atau sama dengan 0,05, Ho tidak dapat ditolak, maka data berdistribusi normal. Model regresi yang baik adalah model regresi yang berdistribusi normal (Ghozali, 2013).

\section{Uji Multikolinearitas}

Uji multikolinearitas bertujuan untuk menguji apakah di dalam suatu model regresi terjadi korelasi antar variabel independen. Multikolinearitas dapat diketahui dari nilai tolerance dan nilai Variance Inflaction
Factor (VIF). Apabila nilai tolerance di atas 0,1 dan Variance Inflaction Factor (VIF) di bawah 10, maka tidak terdapat multikolinearitas. Model regresi yang baik seharusnya tidak terjadi korelasi di antara variabel independennya yang berarti tidak terdapat multikolinearitas (Ghozali, 2013).

\section{Uji Heteroskedastisitas}

Uji heteroskedastisitas dilakukan untuk menguji apakah dalam model regresi terjadi ketidaksamaan variance dari residual satu pengamatan ke pengamatan lainnya. Dalam menentukan ada atau tidaknya heteroskedastisitas pada data dapat dilakukan dengan uji glejser menggunakan nilai absolut residual variabel independen pada tingkat $\alpha=$ $5 \%$. Jika nilai sig. (2-tailed) di atas atau sama dengan 0,05 , Ho tidak dapat ditolak, maka tidak terdapat heteroskedastisitas. Model regresi yang baik adalah model regresi yang memiliki variance yang sama antara satu pengamatan dengan pengamatan lain yang berarti tidak terdapat heteroskedastisitas (Ghozali, 2013).

\section{Uji Autokorelasi}

Ghozali (2013) menyatakan uji autokorelasi bertujuan untuk menguji dalam model regresi linear terdapat korelasi antara kesalahan pengganggu pada periode $t$ dengan kesalahan pengganggu pada periode $\mathrm{t}-1$ atau periode sebelumnya. Dalam menentukan ada atau tidaknya autokorelasi dapat menggunakan uji Lagrange-Multiplier dengan meregresi kesalahan pengganggu pada tingkat $\alpha=5 \%$. Jika nilai sig. (2-tailed) di atas atau sama dengan 0,05 , Ho tidak dapat ditolak, maka tidak terdapat autokorelasi. Model regresi yang baik adalah model regresi yang tidak terdapat korelasi antar variabel independen yang berarti tidak terdapat autokorelasi.

\section{Uji Outlier}

Ghozali (2013) menyatakan outlier merupakan data yang memiliki karakteristik unik yang terlihat sangat berbeda jauh dari observasi-observasi lainnya yang muncul dalam bentuk nilai ekstrim untuk variabel tunggal atau variabel kombinasi. Apabila ditemukan data yang outlier, maka data tersebut harus dikeluarkan dari pengujian statistik dengan mendasarkan pada nilai $\mathrm{z}$ score yang diperoleh dari regresi data residual. Standar nilai $\mathrm{z}$ score yang digunakan yaitu menggunakan kisaran di 
atas 2,5 atau di bawah -2,5 dan kisaran di atas 3 atau di bawah -3 untuk sampel dengan jumlah di atas 80. Pada penelitian ini, standar $z$ score yang digunakan dalam mengeliminasi data yang outlier menggunakan kisaran nilai $\mathrm{z}$ score di atas 2,5 atau di bawah $-2,5$.

\section{Uji Hipotesis}

Adapun model regresi berganda yang digunakan untuk menguji hipotesis dijabarkan ke fungsi linear dalam bentuk persamaan sebagai berikut.

$$
\begin{aligned}
& \mathbf{E M}=\alpha+\beta 1 \text { UK_DK + } \beta 2 \text { DK_IND + } \\
& \beta 3 \text { UK_KA }+\beta 4 \text { KA_IND }+\beta 5 \\
& \text { KA_MEET }+\infty \quad \beta 6 \\
& \text { KA_EXPERT }+\quad \beta 7 \\
& \text { KA_QUALITY + } \beta 8 \text { SIZE + } \beta 9 \\
& \mathrm{CF} \overline{\mathrm{O}}+\mathrm{e}
\end{aligned}
$$

\section{Uji Koefisien Determinasi}

Ghozali (2013) menyatakan koefisien determinasi atau adjusted R-square digunakan untuk mengukur seberapa jauh kemampuan vatiabel independen menjelaskan variasi variabel dependennya, sementara untuk sisa variasi variabel dependen yang tidak dapat dijelaskan merupakan variasi lain yang tidak termasuk dalam model penelitian. Apabila nilai adjusted $R$-square di atas 0,5 atau mendekati 1, berarti kemampuan variabel independen dalam menjelaskan variasi variabel dependennya semakin kuat yang berarti variabel-variabel independen memberikan hampir semua informasi yang dibutuhkan untuk memprediksi variasi variabel dependen.

\section{Uji F}

Uji f digunakan untuk menguji apakah model regresi yang digunakan dalam penelitian ini sudah tepat dan layak digunakan dalam pengambilan keputusan. Apabila nilai sig. (2-tailed) lebih besar dari 0,05 , Ho tidak dapat ditolak, maka model regresi tidak layak digunakan dalam penelitian (Ghozali, 2011).

\section{Uji t}

Uji $t$ bertujuan untuk menguji seberapa besar pengaruh variabel independen secara individual terhadap variabel dependen. Jika nilai sig. (2-tailed) lebih kecil dari atau sama dengan 0,05 , maka Ha tidak dapat ditolak, yang berarti secara individual variabel independen memiliki pengaruh terhadap variabel independen (Ghozali, 2013).

\section{HASIL DAN PEMBAHASAN}

\section{Deskripsi Data/Objek Penelitian}

Tabel 1 menunjukkan hanya 40 perusahaan manufaktur yang dapat dipilih dari 134 perusahaan manufaktur terdaftar di BEI dari tahun 2011-2014 menjadi sampel penelitian sehingga diperoleh keseluruhan data berjumlah 160 data. Data tersebut kemudian dilakukan uji outlier karena tidak memenuhi asumsi normalitas yang mengeliminasi 6 data, sehingga data yang digunakan dalam penelitian ini berjumlah 154 data.

\section{Statistik Deskriptif}

Tabel 2 menunjukkan total data yang digunakan sebagai sampel dalam penelitian ini adalah 154 data. Praktik earnings management memiliki nilai minimum sebesar $-0,1663$ dan nilai maksimum sebesar 0,2757 . Nilai rata-rata praktik earnings management sebesar 0,0008 dan deviasi standar sebesar 0,0710. Ukuran dewan komisaris yang diukur berdasarkan jumlah anggota dewan komisaris memiliki nilai minimum sebesar dua dan nilai maksimum sebesar 12. Ukuran dewan komisaris memiliki nilai rata-rata sebesar lima dan deviasi standar sebesar 2,227. Komposisi dewan komisaris independen memiliki nilai minimum sebesar 0,25 dan nilai maksimum sebesar satu. Nilai ratarata komposisi dewan komisaris independen sebesar 0,4064 dan deviasi standar sebesar 0,1353 .

Ukuran komite audit memiliki nilai minimum sebesar tiga dan nilai maksimum sebesar lima. Nilai rata-rata ukuran komite audit sebesar tiga dan deviasi standar sebesar 0,439. Komposisi komite audit independen memiliki nilai minimum sebesar 0,3333 dan nilai maksimum sebesar 0,75 . Nilai rata-rata komposisi komite audit independen sebesar 0,6383 dan deviasi standar sebesar 0,0763. Jumlah rapat komite audit memiliki nilai minimum sebesar satu dan nilai maksimum sebesar 36 . Nilai rata-rata jumlah rapat komite audit sebesar enam dan deviasi standar sebesar 5,429 . 
Ukuran perusahaan yang diukur dengan proksi logaritma natural total aset memiliki nilai minimum sebesar 98.019.132.648 dan nilai maksimum sebesar 238.029.000.000.000. Ukuran perusahaan memiliki nilai rata-rata sebesar 12.134.408.081.071 dan deviasi standar sebesar 33.145.535.111.804. Aliran kas dari aktivitas operasi memiliki nilai minimum sebesar 0,0002 dan nilai maksimum sebesar 0,6273. Aliran kas dari aktivitas operasi memiliki nilai ratarata sebesar 0,1437 dan deviasi standar sebesar 0,1183. Leverage yang diukur dengan proksi debt to assets ratio memiliki nilai minimum sebesar 0,0977 dan nilai maksimum sebesar 0,8574 . Leverage memiliki nilai rata-rata sebesar 0,4071 dan deviasi standar sebesar 0,1726 .

Tabel 3 menujukkan data anggota komite audit perusahaan manufaktur yang tidak memiliki keahlian keuangan berjumlah 11 data dengan komposisi 7,1 \%. Data anggota komite audit perusahaan manufaktur yang tidak memiliki keahlian keuangan berjumlah 143 data dengan komposisi 92,9\%. Tabel 4 menujukkan data perusahaan yang menggunakan KAP Non Big Four dalam proses pengauditan laporan keuangan berjumlah 64 data dengan komposisi $41,6 \%$. Data perusahaan yang menggunakan KAP Big Four dalam proses pengauditan laporan keuangan berjumlah 90 data dengan komposisi 58,4 \%.

Uji outlier pada penelitian ini mengeliminasi data yang memiliki kriteria nilai z score di atas 2,5 dan di bawah $-2,5$. Hasil pengujian menunjukkan bahwa dari 160 data residual yang dilakukan uji outlier, diperoleh 6 data yang memiliki kriteria $\mathrm{z}$ score di atas 2,5 dan di bawah -2,5. Data tersebut kemudian dieliminasi dari sampel penelitian, sehingga diperoleh data yang digunakan dalam penelitian sebesar 154 data yang akan dilakukan uji normalitas kembali untuk menentukan apakah data sudah berdistribusi normal.

Hasil uji normalitas pada tabel 5 menunjukkan nilai asymp. sig. yang diperoleh sebesar 0,844 yang berarti nilai asymp. sig. di atas 0,05 . Ini berarti Ho tidak dapat ditolak. Hal ini menunjukkan bahwa data terdistribusi normal, sehingga dapat disimpulkan bahwa data penelitian memenuhi asumsi normalitas dan layak digunakan dalam penelitian

Hasil uji multikolinearitas dari tabel 6 menunjukkan bahwa ukuran dewan komisaris, komposisi dewan komisaris independen, ukuran komite audit, komposisi komite audit independen, jumlah rapat komite audit, keahlian keuangan anggota komite audit, kualitas auditor, ukuran perusahaan, dan aliran kas dari aktivitas operasi memiliki nilai tolerance di atas 0,1 dan nilai VIF di bawah 10 . Hal ini berarti bahwa model regresi terbebas dari multikolinearitas dan baik digunakan dalam penelitian.

Hasil uji heteroskedastisitas dari tabel 7 menunjukkan bahwa ukuran dewan komisaris, komposisi dewan komisaris independen, ukuran komite audit, komposisi komite audit independen, jumlah rapat komite audit, keahlian keuangan anggota komite audit, kualitas auditor, ukuran perusahaan, dan aliran kas dari aktivitas operasi memiliki nilai sig. di atas 0,05 . Ini berarti Ho tidak dapat ditolak yang menunjukkan bahwa tidak terdapat heteroskedastisitas pada ukuran dewan komisaris, komposisi dewan komisaris independen, ukuran komite audit, komposisi komite audit independen, jumlah rapat komite audit, keahlian keuangan anggota komite audit, kualitas auditor, ukuran perusahaan, dan aliran kas dari aktivitas operasi.

Hasil uji autokorelasi pada tabel 8 menunjukkan data residual memiliki nilai sig. sebesar 0,730 yang berarti nilai sig. yang diperoleh di atas 0,05 . Ini berarti Ho tidak dapat ditolak yang menunjukkan tidak terdapat autokorelasi pada ukuran dewan komisaris, komposisi dewan komisaris independen, ukuran komite audit, komposisi komite audit independen, jumlah rapat komite audit, keahlian keuangan anggota komite audit, kualitas auditor, ukuran perusahaan, dan aliran kas dari aktivitas operasi dengan nilai absolut residual.

Hasil uji korelasi pada tabel 9 menunjukkan nilai $\mathrm{R}$ bernilai positif yaitu sebesar 0,682 . Nilai koefisien korelasi yang diperoleh lebih besar dari 0,5 yang menunjukkan bahwa terdapat hubungan yang kuat antara ukuran dewan komisaris, komposisi dewan komisaris independen, ukuran komite audit, komposisi komite audit independen, jumlah rapat komite audit, keahlian keuangan anggota komite audit, kualitas auditor, ukuran perusahaan, dan 
aliran kas dari aktivitas operasi dengan praktik earnings management.

Koefisien determinasi yang ditunjukkan oleh nilai adjusted $R$-square pada tabel 9 yaitu sebesar 0,465. Ini berarti 46,5\% besarnya variasi praktik earnings management dapat dijelaskan oleh ukuran dewan komisaris, komposisi dewan komisaris independen, ukuran komite audit, komposisi komite audit independen, jumlah rapat komite audit, keahlian keuangan anggota komite audit, kualitas auditor, ukuran perusahaan, dan aliran kas dari aktivitas operasi. Sisanya yaitu 53,5\% besarnya variasi praktik earnings management dijelaskan oleh faktor-faktor lain yang tidak termasuk dalam model regresi.

Tabel 10 menunjukkan nilai $f$ sebesar 12,409 dan nilai sig. yang diperoleh sebesar 0,000 yang berarti nilai sig. tersebut di bawah 0,05 . Ini berarti Ha tidak dapat ditolak yang berarti model regresi fit atau layak digunakan dalam penelitian. Berdasarkan tabel 11, maka model regresi dapat dirumuskan sebagai berikut.

EM $=-0,361-0,006$ UK DK $+0,091$

DK IND $+0,026$ UK KA $+\mathbf{0 , 0 1 3}$

KA IND - 0,001 KA MEET + 0,009

KA_EXPERT + 0,018 KA_QUALITY

$+0, \overline{0} 13$ SIZE - 0,405 CFO

Koefisien dari ukuran dewan komisaris bernilai negatif sebesar -0,006. Ukuran dewan komisaris memiliki nilai sig. sebesar 0,055 yang berarti lebih besar dari 0,05 . Hal ini menunjukkan bahwa $\mathrm{Ha}_{1}$ ditolak yang berarti ukuran dewan komisaris tidak memiliki pengaruh terhadap praktik earnings management. Jumlah dewan komisaris yang ada pada perusahaan saat ini belum dapat memaksimalkan fungsi dewan komisaris dalam memberikan nasihat pada direksi, melakukan monitoring secara efektif terhadap kinerja direksi, dan memastikan perusahaan menerapkan prinsip good corporate governance.

Koefisien dari komposisi dewan komisaris independen bernilai positif sebesar 0,091. Ukuran dewan komisaris memiliki nilai sig. sebesar 0,005 yang berarti lebih kecil dari 0,05. Hal ini menunjukkan bahwa $\mathrm{Ha}_{2}$ diterima yang berarti komposisi dewan komisaris independen memiliki pengaruh positif terhadap praktik earnings management. Komposisi dewan komisaris independen yang tinggi dapat menyebabkan dewan komisaris independen sulit untuk menjalankan fungsi dan tanggung jawabnya dalam menjalankan komunikasi dan koordinasi dengan anggota dewan komisaris perusahaan lainnya. Hal ini dikarenakan dewan komisaris independen merupakan pihak di luar manajemen perusahaan yang tidak memahami internal perusahaan, sehingga manajemen dapat lebih leluasa untuk melakukan pengaturan laba yang cenderung meningkatkan praktik earnings management.

Koefisien dari ukuran komite audit bernilai positif sebesar 0,026. Ukuran komite audit memiliki nilai sig. sebesar 0,077 yang berarti lebih besar dari 0,05. Hal ini menunjukkan bahwa $\mathrm{Ha}_{3}$ ditolak yang berarti ukuran komite audit tidak memiliki pengaruh terhadap praktik earnings management. Penunjukan anggota komite audit di perusahaan publik sebagian besar bukan didasarkan atas kompetensi dan kapabilitas yang memadai, namun lebih didasarkan pada kedekatan dengan dewan komisaris perusahaan. Anggota komite audit semacam ini sulit diharapkan untuk dapat bekerja secara profesional, sehingga besar kecilnya jumlah komite audit di perusahaan tidak akan bisa membatasi terjadinya praktik earnings management.

Koefisien dari komposisi komite audit independen bernilai positif sebesar 0,013. Komposisi komite audit independen memiliki nilai sig. sebesar 0,432 yang berarti lebih besar dari 0,05 . Hal ini menunjukkan bahwa $\mathrm{Ha}_{4}$ ditolak yang berarti ukuran dewan komisaris tidak memiliki pengaruh terhadap praktik earnings management. Komite audit diketuai oleh komisaris perusahaan, maka keputusan akhir sepenuhnya berada pada komisaris perusahaan yang menyebabkan tidak berfungsinya peran komite audit independen dalam melakukan pengawasan terhadap pelaporan keuangan untuk menurunkan praktik earnings management.

Koefisien dari jumlah rapat komite audit bernilai negatif sebesar $-0,001$. Jumlah rapat komite audit memiliki nilai sig. sebesar 0,153 yang berarti lebih besar dari 0,05 . Hal ini menunjukkan bahwa $\mathrm{Ha}_{5}$ ditolak yang berarti jumlah rapat komite audit tidak memiliki pengaruh terhadap praktik earnings management. Frekuensi rapat komite audit yang semakin tinggi belum dapat memberikan pengawasan yang lebih efektif terhadap pelaporan keuangan oleh manajemen. Anggota komite audit seharusnya dapat melakukan rapat secara 
terpisah dengan manajer, auditor internal, dan auditor eksternal untuk memastikan tidak terjadi pengawasan atas pelaporan keuangan dan proses audit secara berlebihan yang berdampak pada penurunan kualitas informasi keuangan perusahaan.

Koefisien dari keahlian keuangan anggota komite audit bernilai positif sebesar 0,009. Keahlian keuangan anggota komite audit memiliki nilai sig. sebesar 0,307 yang berarti lebih besar dari 0,05 . Hal ini menunjukkan bahwa $\mathrm{Ha}_{6}$ ditolak yang berarti keahlian keuangan anggota komite audit tidak memiliki pengaruh terhadap praktik earnings management. Meskipun terdapat anggota komite audit yang memiliki keahlian keuangan yang memadai, hal tersebut belum mampu membatasi praktik earnings management yang dilakukan manajemen. Hal ini terkait dengan fungsi komite audit yang hanya memberikan pengawasan sepenuhnya atas pelaporan keuangan perusahaan dan keputusan komite audit diserahkan sepenuhnya pada komisaris perusahaan yang dapat bertindak sesuai dengan kepentingan pemegang saham.

Koefisien dari kualitas auditor bernilai positif sebesar 0,018. Kualitas auditor memiliki nilai sig. sebesar 0,097 yang berarti lebih besar dari 0,05 . Hal ini menunjukkan bahwa $\mathrm{Ha}_{7}$ ditolak yang berarti kualitas auditor tidak memiliki pengaruh terhadap praktik earnings management. Auditor yang berasal dari KAP Big Four kurang dapat menjalankan tugas dengan semestinya karena adanya intervensi manajemen dalam menyiapkan laporan keuangan, sehingga integritas mereka sebagai auditor eksternal kurang berfungsi sebagaimana semestinya.

Koefisien dari ukuran perusahaan bernilai positif sebesar 0,013. Ukuran perusahaan memiliki nilai sig. sebesar 0,004 yang berarti lebih kecil dari 0,05. Hal ini menunjukkan bahwa $\mathrm{Ha}_{7}$ diterima yang berarti ukuran perusahaan memiliki pengaruh positif terhadap praktik earnings management. Perusahaan yang berukuran besar memiliki kepercayaan pasar yang kuat bahwa perusahaan mampu menyediakan informasi keuangan yang akurat. Hasil penelitian ini sesuai dengan teori size hypothesis yang dikemukakan Watt dan Zimmerman (1986) yang menyatakan bahwa perusahaan berukuran besar secara politis memperoleh perhatian dari berbagai pihak seperti analis keuangan dan pemerintah, sehingga perusahaan besar cenderung melakukan praktik earnings management dibandingkan dengan perusahaan kecil.

Koefisien dari aliran kas dari aktivitas operasi bernilai negatif sebesar -0,405. Aliran kas dari aktivitas operasi memiliki nilai sig. sebesar 0,000 yang lebih kecil dari 0,05. Hal ini menunjukkan bahwa $\mathrm{Ha}_{8}$ diterima yang berarti aliran kas dari aktivitas operasi memiliki pengaruh positif terhadap praktik earnings management. Perusahaan dengan aliran kas dari aktivitas operasi yang tinggi akan cenderung menurunkan praktik earnings management dikarenakan perusahaan sudah memiliki kinerja operasi yang baik. Sebaliknya, perusahaan yang memiliki aliran kas dari aktivitas operasi yang rendah kemungkinan besar akan mempengaruhi pendapatannya dengan meningkatkan praktik earnings management untuk mengirimkan sinyal positif ke investor bahwa perusahaan tetap memiliki kinerja keuangan yang baik.

\section{SIMPULAN DAN SARAN}

\section{Simpulan}

1. Ukuran dewan komisaris tidak berpengaruh terhadap praktik earnings management. Hasil penelitian ini tidak sejalan dengan Jao dan Pagulung (2012) dan Murtini dan Mansyur (2012), namun sejalan dengan Ratnaningsih dan Hidayati (2012) serta Nugroho dan Eko (2011).

2. Komposisi dewan komisaris independen berpengaruh positif terhadap praktik earnings management. Hasil penelitian ini tidak sejalan dengan Murtini dan Mansyur (2012) dan Jao dan Pagalung (2012). Hasil penelitian ini sejalan dengan Agustia (2013) serta Nugroho dan Eko (2011).

3. Ukuran komite audit tidak berpengaruh terhadap praktik earnings management. Hasil penelitian ini sejalan dengan. Baxter and Cotter (2009), namun sejalan dengan Soliman dan Ragab (2014) dan Agustia (2013).

4. Komposisi komite audit independen tidak berpengaruh terhadap praktik earnings management. Hasil penelitian ini tidak sejalan dengan Soliman dan Ragab (2014) serta Waweru dan Riro (2013).

5. Jumlah rapat komite audit tidak berpengaruh terhadap praktik earnings 
management. Hasil penelitian ini tidak sejalan dengan Soliman dan Ragab (2014), Metawee (2013), dan Jao dan Pagulung (2011).

6. Keahlian keuangan anggota komite audit tidak berpengaruh terhadap praktik earnings management. Hasil penelitian ini tidak sejalan dengan Soliman dan Ragab (2014) dan Metawee (2013).

7. Kualitas auditor tidak berpengaruh terhadap praktik earnings management.

Hasil penelitian ini tidak sejalan dengan Soliman dan Ragab (2014), namun hasil penelitian ini sejalan dengan Murtini dan Mansyur (2012).

8. Ukuran perusahaan berpengaruh positif terhadap praktik earnings management. Hasil penelitian ini sejalan dengan Patrick, et.al (2015), Fanani (2014), dan Rauf, et. al (2012).

9. Aliran kas dari aktivitas operasi berpengaruh negatif terhadap praktik earnings management. Hasil penelitian ini sejalan dengan Soliman dan Ragab (2014), Sukeecheep, et.al (2013 dan Rauf, et. al (2012).

\section{Saran}

1. Peneliti selanjutnya dapat menambah atau meneliti sektor perusahaan lainnya yaitu perusahaan non manufaktur. Hal ini untuk menentukan seberapa luas good corporate governance dapat mempengaruhi praktik earnings management yang dilakukan oleh sektor perusahaan selain perusahaan manufaktur yang telah diuji oleh peneliti.

2. Peneliti selanjutnya dapat menambah proksi good corporate governance lainnya yang mempengaruhi praktik earnings management seperti kepemilikan manajerial dan kepemilikan institusional

3. Peneliti selanjutnya dapat menambah sampel perusahaan manufaktur yang memiliki aliran kas dari aktivitas operasi yang negatif, sehingga dapat membuktikan seberapa besar pengaruh good corporate governance pada perusahaan yang memiliki aliran kas dari aktivitas operasi yang negatif.

\section{DAFTAR PUSTAKA}

Agustia, Dian. (2013). Pengaruh Faktor Good Corporate Governance, Free Cash Flows, dan Leverage terhadap Manajemen Laba. Jurnal Akuntansi dan Keuangan, Vol. 11, No. 1 : 2742.

Baxter P dan Cotter J. (2009). Audit committee and earnings quality. Accounting and Finance, Vol. 49(3), 267-290.

Bloomberg. Toshiba Diguncang Skandal Akuntansi Senilai US \$1,2 Miliar. www.bisnis.com/finansial/read/20150721/9/4 55185/.

Bukit, R.B dan T.M. Iskandar. (2009). Surplus Free Cash Flow, Earnings Management, and Audit Committee. International Journal of Economics and Management, Vol. 3, 204-223.

Bursa Efek Indonesia. (2011). Pedoman Tata Kelola Perusahaan (Code of Corporate Governance). Versi 1.0. Jakarta : Bursa Efek Indonesia.

Fanani, Zaenal. (2014). Karakteristik Perusahaan dan Corporate Governance Terhadap Manajemen Laba : Studi Analisis Meta. Jurnal Keuangan dan Perbankan, Vol. 18, No. 2: 181-200.

Ghozali, Imam. (2013). Aplikasi Analisis Multivariate dengan Program SPSS. Semarang : Badan Penerbit Universitas Diponegoro.

Godfrey, J.H.; T. Hamilton; dan Holmes. (2013). Accounting Theory. $7^{\text {th }}$ Edition. Queensland : John Wiley and Sons Inc.

Guna, W.I dan A. Herawaty. (2010). Pengaruh Mekanisme Good Corporate Governance, Independensi Auditor, Kualitas Audit, dan Faktor Lainnya terhadap Manajemen Laba. Jurnal Bisnis dan Akuntansi, No. 1: 53-68.

Hassan, S.U dan A. Ahmed. (2012). Corporate Governance, Earnings Management and Financial Performance : A Case of Nigerian Manufacturing Firms. American International Journal of Contemporary Research, Vol. 2, No. 7: 214-226. 
Jao, Robert dan G. Pagulung. (2011). Corporate Governance, Ukuran Perusahaan, dan Leverage terhadap Manajemen Laba Perusahaan Manufaktur Indonesia. Jurnal Akuntansi dan Auditing, Vol. 8, No. 1.

Jensen, M.C. dan W.H. Meckling. (1976). Theory of The Firm : Managerial Behavior, Agency Cost, and Ownership Structure. Journal of Financial Economics, No. 3: 305360.

Kieso, D.E.; J.J. Weygandt; dan T.D. Warfield. (2012). Intermediate Accounting. $\quad 14^{\text {th }} \quad$ Edition. Queensland : John Wiley and Sons Inc.

Komite Nasional Kebijakan Governance. (2006). Pedoman Umum Good Corporate Governance. Jakarta : Komite Nasional Kebijakan Governance.

Metawee, A.K. (2013). The Relationship Between Characteristic of Audit Commitee, Board of Directors, and Level of Earnings management, Evidence from Egypt. Journal of International Business and Finance.

Murtini, Umi dan R. Mansyur. (2012). Pengaruh Corporate Governance terhadap Manajemen Laba Perusahaan di Indonesia. JRAK, Vol. 8, No. 1.

Natalia, Debby dan P.L. Eko. (2013). Pengaruh Mekanisme Good Corporate Governance terhadap Praktik Earnings Management Badan Usaha Sektor Perbankan di BEI 2008-2011. Jurnal Ilmiah Mahasiswa Universitas Surabaya, Vol. 2 No.1.

Nugroho, Y.B dan U. Eko. (2012). Board Characteristics and Earnings Management. Journal of Administrative Science \& Organization, Vol. 18, No. 1: 1-10.

Patrick, E.A; E.C. Paulinus; dan A.N. Nympha. (2015). The Influence of Corporate Governance on Earnings Management Practices : A Study of Some Selected Quoted Companies in Nigeria. American Journal of Economics, Finance and Management, Vol. 1, No. 5: 482493.

Purnomo, Budi dan P. Pratiwi. (2009). Pengaruh Earning Power terhadap
Praktik Manajemen Laba (Earnings Management). Jurnal Media Ekonomi, Vol. 14, No. 1: 1-13.

Purwanti, Meilani dan Aceng Kurniawan (2013). The Effect of Earnings Management and Disclosure on Information Asymmetry. International Journal of Scientific and Technology Research, Vol. 2, No. 8: 98-107.

Rahmani, Samira dan M.A. Akbari. (2013). Impact of Firm Size and Capital Structure on Earnings Management : Evidence from Iran. World of Sciences Journal, Vol. 1, No. 17: 59-71.

Ratnaningsih dan C. Hidayati. (2012). Pengaruh Corporate Governance terhadap Manajemen Laba pada Perusahaan Perbankan yang Terdaftar di Bursa Efek Indonesia. Media Mahardhika, Vol.10, No. 3.

Rauf, F.H.A; N.H. Johari; S. Buniamin; dan N.R.A. Rahman. (2012). The Impact of Company and Board of Characteristics on Earnings Management : Evidence from Malaysia. Global Review of Accounting and Finance, Vol.3, No. $2: 114-127$.

Scott, William. (2013). Financial Accounting Theory. $3^{\text {rd }}$ Edition. New Jersey : Prentice-Hall Inc.

Siam, Y.I.S.A; N.H.B. Laili; dan K.F.B. Khairi. (2014). Boar of Directors and Earning Management Among Jordanian Listed Companies : Proposing Conceptual Framework. International Journal of Technical Research and Applications, Vol. 2, No. 3: 1-7.

Soliman, M.M dan A.A. Ragab. (2014). Audit Committee Effectiveness, Audit Quality and Earnings Management : An Empiritical Study of the Listed Companies in Egypt. Research Journal of Finance and Accounting, Vol. 5, No.2: 155-166.

Sriwedari, Tuti. (2012). Mekanisme Good Corporate Governance, Manajemen Laba dan Kinerja Keuangan Perusahaan Manufaktur di Bursa Efek Indonesia. Jurnal Mediasi, Vol. 4, No. 1.

Sukeecheep, Supawadee, S.R. Yarram, dan O.A. Farooque. (2013). Earnings Management and Board Characteristics in Thai Listed 
Companies. The 2013 International Conference on Business, Economics, and Accounting.

Utami, Sri dan S.D. Prastiti. (2011). Pengaruh Karakteristik Perusahaan terhadap Social Disclosure. Jurnal Ekonomi Bisnis, Vol.6, No. 1, pp. 63-69.

Wardhani, Ratna dan H. Joseph. (2010). Karakteristtik Pribadi Komite Audit dan Praktik Manajemen Laba. Simposium Nasional Akuntansi XIII Purwokerto.

Wahyono, R. E. S; Wahidahwati; dan A. Sunaryo. (2013). Pengaruh Corporate Governance pada Praktik Manajemen Laba : Studi pada Industri Perbankan Indonesia. Jurnal Ilmu dan Riset Akuntansi, Vol. 1, No.2: 187-206.

Waweru, N.M dan G.K. Riro. (2013). Corporate Governance, Firm Characteristics and Earnings Management in An Emerging Economy. JAMAR, Vol. 11, No.1: 43-64. 


\section{LAMPIRAN}

\section{Gambar 1. Skema Kerangka Pemikiran}

\section{Variabel Independen}

Corporate Governance

Ukuran Dewan Komisaris $\left(\mathrm{X}_{1}\right)$

Komposisi Dewan Komisaris Independen

$\left(\mathrm{X}_{2}\right)$

Ukuran Komite Audit ( $\left.\mathrm{X}_{3}\right)$

Komposisi Komite Audit Independen $\left(\mathrm{X}_{4}\right)$

Jumlah Rapat Komite Audit $\left(\mathrm{X}_{5}\right)$

Keahlian Keuangan Anggota Komite Audit

$\left(\mathrm{X}_{6}\right)$

Kualitas Auditor $\left(\mathrm{X}_{7}\right)$

Ukuran Perusahaan $\left(\mathrm{X}_{8}\right)$

Aliran Kas dari Aktivitas Operasi $\left(\mathrm{X}_{9}\right)$

Sumber : Hasil Olahan Penulis

\section{Hasil Pengujian Output SPSS}

\section{Tabel 1. Prosedur Pemilihan Sampel}

\begin{tabular}{|l|l|r|r|}
\hline No. & \multicolumn{1}{|c|}{ Deskripsi Kriteria } & \multicolumn{1}{|c|}{$\begin{array}{c}\text { Jumlah } \\
\text { Perusahaan }\end{array}$} & $\begin{array}{c}\text { Jumlah } \\
\text { Data }\end{array}$ \\
\hline 1. & $\begin{array}{l}\text { Perusahaan manufaktur yang terdaftar di Bursa Efek } \\
\text { Indonesia secara konsisten dari tahun 2011-2014. }\end{array}$ & 134 & 536 \\
\hline 2. & $\begin{array}{l}\text { Perusahaan yang tidak menerbitkan laporan keuangan pada } \\
\text { akhir tahun fiskal 31 Desember. }\end{array}$ & $(2)$ & $(8)$ \\
\hline 3. & $\begin{array}{l}\text { Perusahaan yang tidak menerbitkan laporan keuangan dalam } \\
\text { mata uang rupiah. }\end{array}$ & $(24)$ & $(96)$ \\
\hline 4. & $\begin{array}{l}\text { Perusahaan yang memiliki aliran kas bersih dari aktivitas } \\
\text { operasi yang negatif. }\end{array}$ & $(55)$ & $(220)$ \\
\hline 5. & $\begin{array}{l}\text { Perusahaan yang tidak mengungkapkan informasi } \\
\text { good corporate governance secara lengkap dalam } \\
\text { laporan tahunan. }\end{array}$ & $(13)$ & $(52)$ \\
\hline & Total Data & 40 & 160 \\
\hline & Data yang outlier & & $(6)$ \\
\hline & Jumlah Sampel & & 154 \\
\hline
\end{tabular}

Tabel 2. Statistik Deskriptif

\begin{tabular}{|c|r|r|r|r|}
\hline Variabel & Minimum & Maksimum & Rata-rata & \multicolumn{1}{c|}{$\begin{array}{c}\text { Deviasi } \\
\text { Standar }\end{array}$} \\
\hline Praktik Earnings Management & $-0,1663$ & 0,2757 & 0,0008 & 0,0710 \\
\hline
\end{tabular}




\begin{tabular}{|l|r|r|r|r|}
\hline Ukuran Dewan Komisaris & 2 & 12 & 5 & 2,227 \\
\hline $\begin{array}{l}\text { Komposisi Dewan Komisaris } \\
\text { Independen }\end{array}$ & 0,25 & 1 & 0,4064 & 0,1353 \\
\hline Ukuran Komite Audit & 3 & 5 & 3 & 0,439 \\
\hline $\begin{array}{l}\text { Komposisi Komite Audit } \\
\text { Independen }\end{array}$ & 0,3333 & 0,75 & 0,6383 & 0,0763 \\
\hline Jumlah Rapat Komite Audit & 1 & 36 & 6 & 5,4029 \\
\hline Ukuran Perusahaan & 98.019 .132 & 236.029 .000$. & 12.134 .408 .0 & 33.145 .535 .1 \\
& .648 & 000.000 & 81.071 & 11.804 \\
\hline Aliran Kas dari Aktivitas Operasi & 0,0002 & 0,6273 & 0,1437 & 0,1183 \\
\hline
\end{tabular}

Tabel 3. Frekuensi Keahlian Keuangan Anggota Komite Audit

\begin{tabular}{|l|l|r|r|r|r|}
\hline & $\begin{array}{l}\text { Keahlian Keuangan } \\
\text { Anggota Komite Audit }\end{array}$ & Frekuensi & Persentase & \multicolumn{1}{|c|}{$\begin{array}{c}\text { Persentase } \\
\text { Valid }\end{array}$} & \multicolumn{1}{|c|}{$\begin{array}{c}\text { Persentase } \\
\text { Kumulatif }\end{array}$} \\
\hline Valid & $\begin{array}{l}\text { Tidak Memiliki } \\
\text { Keahlian Keuangan }\end{array}$ & 11 & 7,1 & 7,1 & 7,1 \\
\cline { 2 - 6 } & $\begin{array}{l}\text { Memiliki Keahlian } \\
\text { Keuangan }\end{array}$ & 143 & 92,9 & 92,9 & 100,0 \\
\hline Total & 154 & 100,0 & 100,0 & 100,0 \\
\hline
\end{tabular}

Tabel 4. Frekuensi Kualitas Auditor

\begin{tabular}{|l|l|r|r|r|r|}
\hline & Kualitas Auditor & Frekuensi & Persentase & $\begin{array}{c}\text { Persentase } \\
\text { Valid }\end{array}$ & $\begin{array}{l}\text { Persentase } \\
\text { Kumulatif }\end{array}$ \\
\hline Valid & KAP Non Big Four & 64 & 41,6 & 41,6 & 41,6 \\
\cline { 2 - 6 } & KAP Big Four & 90 & 58,4 & 58,4 & 100,0 \\
\hline & Total & 154 & 100,0 & 100,0 & 100,0 \\
\hline
\end{tabular}

\section{Tabel 5. Hasil Uji Normalitas}

\begin{tabular}{|c|c|c|}
\hline Model & Asymp. Sig. & Kesimpulan \\
\hline & 0,844 & Data terdistribusi normal \\
\hline
\end{tabular}

\section{Tabel 6. Hasil Uji Multikolinearitas}

\begin{tabular}{|l|r|r|l|}
\hline \multicolumn{1}{|c|}{ Variabel } & \multicolumn{1}{|c|}{ Tolerance } & \multicolumn{1}{c|}{ VIF } & \multicolumn{1}{c|}{ Kesimpulan } \\
\hline Ukuran Dewan Komisaris & 0,304 & 3,289 & Tidak terdapat multikolinearitas \\
\hline $\begin{array}{l}\text { Komposisi Dewan Komisaris } \\
\text { Independen }\end{array}$ & 0,844 & 1,184 & Tidak terdapat multikolinearitas \\
\hline Ukuran Komite Audit Audit & 0,298 & 3,358 & Tidak terdapat multikolinearitas \\
\hline $\begin{array}{l}\text { Komposisi Komite } \\
\text { Independen }\end{array}$ & 0,581 & 1,721 & Tidak terdapat multikolinearitas \\
\hline Jumlah Rapat Komite Audit & 0,351 & 2,850 & Tidak terdapat multikolinearitas \\
\hline $\begin{array}{l}\text { Keahlian Keuangan Anggota } \\
\text { Komite Audit }\end{array}$ & 0,819 & 1,221 & Tidak terdapat multikolinearitas \\
\hline Kualitas Auditor & 0,385 & 2,600 & Tidak terdapat multikolinearitas \\
\hline Ukuran Perusahaan Aktivitas & 0,306 & 3,268 & Tidak terdapat multikolinearitas \\
\hline $\begin{array}{l}\text { Aliran Kas dari } \\
\text { Operasi }\end{array}$ & 0,692 & 1,446 & Tidak terdapat multikolinearitas \\
\hline
\end{tabular}

Tabel 7. Hasil Uji Heteroskedastisitas

\begin{tabular}{|l|l|l|}
\hline \multicolumn{1}{|c|}{ Variabel } & Sig. & \multicolumn{1}{c|}{ Kesimpulan } \\
\hline Ukuran Dewan Komisaris & 0,781 & Tidak terdapat heteroskedastisitas \\
\hline Komposisi Dewan Komisaris Independen & 0,212 & Tidak terdapat heteroskedastisitas \\
\hline Ukuran Komite Audit & 0,761 & Tidak terdapat heteroskedastisitas \\
\hline Komposisi Komite Audit Independen & 0,065 & Tidak terdapat heteroskedastisitas \\
\hline
\end{tabular}




\begin{tabular}{|l|r|l|}
\hline Jumlah Rapat Komite Audit & 0,201 & Tidak terdapat heteroskedastisitas \\
\hline Keahlian Keuangan Anggota Komite Audit & 0,467 & Tidak terdapat heteroskedastisitas \\
\hline Kualitas Auditor & 0,562 & Tidak terdapat heteroskedastisitas \\
\hline Ukuran Perusahaan & 0,635 & Tidak terdapat heteroskedastisitas \\
\hline Aliran Kas dari Aktivitas Operasi & 0,985 & Tidak terdapat heteroskedastisitas \\
\hline
\end{tabular}

Tabel 8. Hasil Uji Autokorelasi

\begin{tabular}{|c|c|c|}
\hline Model & Sig. & Kesimpulan \\
\hline 1 & 0,730 & Tidak terdapat autokorelasi \\
\hline
\end{tabular}

Tabel 9. Uji Korelasi dan Koefisien Determinasi

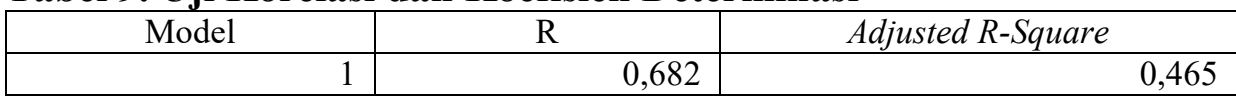

Tabel 10. Hasil Uji F

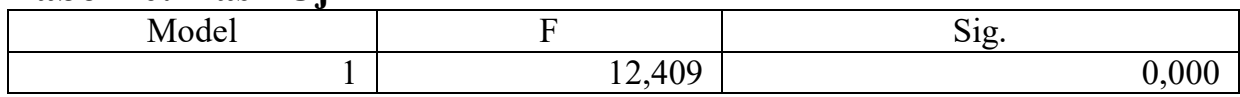

Tabel 11. Hasil Uji T

\begin{tabular}{|l|r|r|r|l|}
\hline \multicolumn{1}{|c|}{ Variabel } & \multicolumn{1}{c|}{ Koefisien } & \multicolumn{1}{c|}{ T } & \multicolumn{1}{c|}{ Sig. } & Keputusan \\
\hline Konstanta & $-0,361$ & $-2,376$ & 0,019 & \\
\hline Ukuran Dewan Komisaris & $-0,006$ & $-1,610$ & 0,055 & $\mathrm{Ha}_{1}$ ditolak \\
\hline $\begin{array}{l}\text { Komposisi Dewan Komisaris } \\
\text { Independen }\end{array}$ & 0,091 & 2,613 & 0,005 & $\mathrm{Ha}_{2}$ ditolak \\
\hline Ukuran Komite Audit & 0,026 & 1,429 & 0,077 & $\mathrm{Ha}_{3}$ ditolak \\
\hline Komposisi Komite Audit Independen & 0,013 & 0,171 & 0,432 & $\mathrm{Ha}_{4}$ ditolak \\
\hline Jumlah Rapat Komite Audit & $-0,001$ & $-1,028$ & 0,153 & $\mathrm{Ha}_{5}$ ditolak \\
\hline $\begin{array}{l}\text { Keahlian Keuangan Anggota Komite } \\
\text { Audit }\end{array}$ & 0,009 & 0,505 & 0,307 & $\mathrm{Ha}_{6}$ ditolak \\
\hline Kualitas Auditor & 0,018 & 1,302 & 0,097 & $\mathrm{Ha}_{7}$ ditolak \\
\hline Ukuran Perusahaan & 0,013 & 2,707 & 0,004 & $\mathrm{Ha}$ diterima \\
\hline Aliran Kas dari Aktivitas Operasi & $-0,405$ & $-9,178$ & 0,000 & $\mathrm{Ha}$ diterima \\
\hline
\end{tabular}

